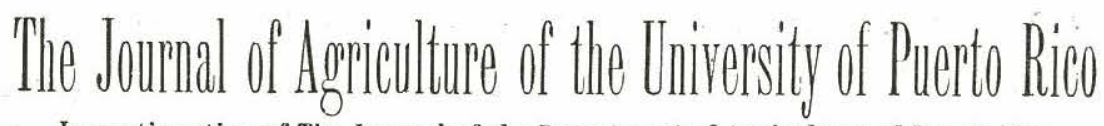

In continuation of The Journal of the Department of Agriculture of Puerto Rico

Published Quarterly: January, A pril, July and 0ctober of each year.

Melville T. CoOK, Edtor

VoL. XIX.

OCTOBER 1935

No. 4.

\title{
INVESTIGATIONS CONCERNING CUBAN BIRDS, WITH SPE- CIAI REFERENCE TO THEIR ECONOMIC STATUS, AND CONSIDERATION OF THOSE WHICH IVIGHT BE DE- SIRABLE FOR INTRODUCTION INTO PUERTO RICO
}

By Stuart T. Danforth

\section{INTRODUCTION}

The material for this paper was obtained during two short visits to Cuba during the summers of 1933 and 1934. On both trips the writer was accompanied by Mr. Virgilio Biaggi, Jr., who assisted in the work materially by the preparation of specimens and in other ways.

During the periods of both visits it proved impossible to use firearms for collecting, due to disturbed political conditions in the island. At first we feared we would have to give up any ideas of collecting, but that was before we had become acquainted with the great skill which many Cuban boys have developed with a slingshot or catapult. We found it possible by employing them to obtain almost any bird we wanted, and on oceasion in embarrassingly large quantities.

\section{ITINERARY}

In 1933 we arrived at Santiago de Cuba early in the morning of June 30, and spent that day in the vicinity of Santiago as guests of Mr. G. C. Bucher, who gave us much valuable information, and showed us some interesting local birds, in addition to offering most generous hospitality.

July 1 we went by bus along the Carretera Central to Sancti Spiritus, observing many birds from the bus en route. We spent the day of July 2 at Sancti Spiritus observing birds, and with the aid of a local boy who was adept with a slingshot we obtained a number of specimens. Señor Raúl Guitart, a distinguished local naturalist and principal of the "Colegio Carlos de la Torre" was of great assistance to us in this town, and we took much pleasure in examining the collection of natural history specimens he is accumulating at this school. 
July 3 we continued by bus along the Carretera Central to Havana, and on July 5 we continued by train thru Pinar del Río to Guane, in extreme western Cuba. Part of the province of Pinar del Río thru which we passed had been devastated by a hurricane three days previously, and in all that part of the island the streams were much swollen as a result of the hurricane rains. We reached Guane soon after noon, and immediately gathered up some local boys and set them collecting birds with slingshots. Towards evening they began bringing them in by the scores. The next morning the birds came in by hundreds instead of scores, and we had so many more birds than it would be possible to skin that we were forced to announce that no more would be accepted after noon. At that hour, in self defense, we were compelled to lock our doors to keep out the additional hundreds that kept arriving despite our announcement. Even so before the time came to take the night train to Pinar del Río we were able to skin only the cream of those we had accepted.

July 7 we went by ear to the limestone sierra beyond Viñales, where we had an opportunity to witness an interesting method of catching birds alive, employed by birdcatchers who obtain cage bird for sale. They work with a very long, slender rod in three sections, easily assembled in the field. At the tip they attach a small twig dipped in bird lime. They sneak up behind a perehing bird, and touch it on the wing with the bird lime. The bird immediately falls screaming to the ground, unable to fly, with the twig soaked in bird lime attached to its wing. Most of the smaller birds were too much glued up by the bird lime to serve as scientific specimens, but we obtained a trogon in fine condition by this method.

July 8 we returned by train to Havana. July 10 and 11 were spent in a bus trip from Havana back to Santiago. As the bus had frequent attacks of engine trouble it gave us chances for a number of unexpected stops where observations could be made. July 12 we sailed from Santiago for Puerto Rico.

The second short visit in 1934 we owed to a prolonged stop for the purpose of loading sugar at Caibarien made by a freighter on which we were travelling. Due to shallow water, boats loading at Caibarien are obliged to anchor near Cayo Francés, fourteen miles from the town of Caibarien and the Cuban mainland. Our boat, after skirting along the coast of Cayo Santa María, arrived at Cayo Francés the latter part of the morning of June 14. That afternoon we obtained permission to take our guns ashore on Cayo Francés, where we collected a few birds, but found the avifauna very meager. June 
15 we went ashore at Caibarien, and the next day went by automobile to Havana, stopping at intervals for bird observations. We returned to Caibarien on June 18, and spent the 19th and most of the 20th working around that town. Boys brought us a few specimens there. We went back to the boat the evening of the 20th, and it sailed the afternoon of June 21, but not before we had opportunity to collect a few birds that came around the boat, including a Leach's Petrel. We observed a few other birds as the boat continued along the coast that afternoon.

On these two trips a total of sixty-seven species of birds were observed, and specimens of thirty-four species were obtained despite the prohibition of the use of firearms.

\section{EoONomic Notes}

The stomachs of most of the birds obtained were preserved, and later their contents were examined in an effort to learn something about the economic status of Cuban birds. The results of this serutiny are given under the various species in the annotated list of birds. Very little has been published on the food habits and economic status of West Indian birds outside of Puerto Rico, so it seems desirable to record any bits of information that may be obtained upon the subject.

At the time of my visit to Guane that region was experiencing a severe infestation of eutworms. Apparently a great variety of birds were attracted by this abundant and easily available source of food, as eutworms were found in the stomachs of eleven species of birds collected at this time in amounts ranging from 6.3 to 90.5 per cent by bulk of their total food. It might be of interest to append a list of these species together with the percentage of total food which cutworms formed in each case:
1. Sturnella magna hippocrepis
90.5
2. Minus polyglottos orpheus
85.0
3. Falco sparverius sparverioides
68. 0
4. Agelaius humeralis
55.0
5. Ptiloxena atroviolacea
45. 0
6. Mimocichla rubripes rubripes
40. 0
7. Ioterus hypomelas
24. 0
8. Tolmarchus caudifasciatus
14. 1
9. Saurothera merlini
11. 7
10. Centrus superciliaris supercitiaris
8. 8
11. Colinus cubanensis
6.3

Ptiloxena atroviolacea in an economically noteworthy bird, due both to the large proportion of eutworms eaten, and to the great 
number of cattle ticks consumed, as many as fifty-eight being found in a single stomach. The possibilities of the value of this bird for introduction to other places should be considered.

Special attention is also called to Saurothera merlini. The stomachs of this species examined were jammed with an enormous number of large insects mostly of an injurious nature. One stomach contained among other items sixteen large tobacco-worms (Protoparce sexta). At that rate one Saurothera could save a tobacco grower many dollars in the course of a season. Many other birds discussed in the pages that follow show very valuable food habits.

\section{ANNotated List}

1. Podilymbus podiceps antillarum Bangs. West Indian Piedbilled Grebe. Zaramagullón. One noted at Palacios July 5, 1933.

2. Oceanodroma leucorhoa leucorhoa (Vieillot). Leach's Petrel. On June 20 and 21, 1934, about eight were feeding around the S.S. "Almeria Lykes" while it was anchored half a mile off Cayo Francés. On the latter date a female was collected, constituting the first record of this species for Cuba, and one of the few records for the West Indies.

3. Pelecanus occidentalis occidentalis Linnaeus. West Indian Brown Pelican. Alcatraz. Seen at Santiago June 30, 1933; Cayo Francés June 14, 1934, and Caibarien June 20, 1934.

4. Phalacrocorax auritus floridanus (Audubon). Florida Cormorant. Corua. Common between Cayo Francés and Caibarien from June 14 to 20, 1934.

5. Fregata magnificens rothschildi Mathews. Man-o-war Bird. Rabihorcado. Noted at Santiago June 30 and July 12, 1933; Cayo Francés June 14 and 20, 1934; Caibarien June 16, 1934, and Matanzas June 16, 1934.

6. Casmerodius albus egretta (Gmelin). American Egret. Garzón. Two seen at Santiago July 12, 1933.

7. Egretta thula thula (Molina). Snowy Egret. Garza Blanca. One noted at Sábalo July 5, 1933, and one at Cascajal June 18, 1934.

8. Hydranassa tricolor ruficollis (Gosse). Lo u isian a Heron. Garza. One seen at Boca de Galafre July 5, and two at Santiago July 12, 1933.

9. Florida caerulea caerulescens (Latham). Southern Little Blue Heron. Garza. Common. Observed at the following localities: Santiago, Palma de Soriano, Bayamo, Santo Domingo, Manacas, Oceguera, Boca de Galafre, Cascajal, Jiguaní, and Matanzas. 
10. Butorides virescens maculatus (Boddaert). West Indian Green Heron. Aguaita Caimán. Common. Recorded at Bayamo, Sancti Spiritus, Santo Domingo, Camagüey, Puerta de Golpe, Pinar del Río, San Juan, Sábalo and Oceguera.

11. Dendrocygna arborea (Linnaeus). West Indian Tree Duck. Yaguasa. One seen near. Sabanicú July 1, 1933.

12. Cathartes aura aura (Linnaeus). Turkey Vulture. Aura. Abundant everywhere on the main island. Two seen on Cayo Francés June 14, 1934.

13. Falco sparverius sparverioides Vigors. Cuban Sparrow Hawk. Cernícalo. Common. Noted at many localities. Three were obtained at Guane July 6, 1933, and two at Caibarien June 20, 1934. This series of five shows specimens grading all the way between the typical rufous phase and the typical light phase. The three stomachs from Guane contained 68 per cent of cutworms; field crickets (Gryllus assimilis), 10 per cent; larvae of Carabid beetles, 10 per cent; large ground spiders, 7.3 per cent; and earwigs 4.7 per cent. These birds had eaten 56, 13 and 4 cutworms apiece.

14. Colinus cubanensis (G. R. Gray). Cuban Quail. Codorniz. Common in the savanna lands. Seen at Ciego de Avila, Sancti Spiritus, Placetas, Rincón, Salud, Sábalo, Pinar del Río, Guane, Candelaria and Jiguaní. A pair was obtained at Guane on July 6, 1933. Their stomachs contained 36 per cent of animal matter and 64 per cent of vegetable matter. The former consisted of 14 Geometrid larvae in one stomach, and a large eutworm, a Coreid bug and an Exopthalmoides weevil in the other. The vegetable matter consisted of small drupes, berries and seeds.

15. Grus mexicanus nesiotes Bangs and Zappey. Cuban Sandhill Crane. Grulla. One was seen near Ciego de Avila on July 1, 1933.

16. Rallus elegans ramsdeni Riley. Cuban King Rail. Martillo. The martillo was well known and said not to be rare in the vicinity of Guane. On July 6, 1933, boys brought me a male which they had obtained with a slingshot. This specimen shows the following measurements: wing 149.7 ; tail 56.9 ; culmen from base 62.0 ; tarsus 54.5 millimeters. Its stomach contained 2 large aquatic Coleoptera larvae; 2 Dytiscid beetles (Thermoneces sp.). 1 Hydrophilid beetle (Hydrous tenebroides), and 2 Lepidopterous larvae.

17. Ionornis martinicus (Linnaeus). Purple Gallinule. Gallareta Azul. In 1933 single birds were noted at Bayamo July 1, Pinar del Río July 5, and Paso Real July 8. 
18. Fulica sp. A coot of some species was seen in a swamp at Contramaestre on July 1, 1933.

19. Jacana spinosa violacea (Cory). West Indian Jacana. Gallito. Observed in 1933 on July 1 at Contramaestre; on July 5 at Paso Real, San Juan and Sábalo; on July 7 at Pinar del Río; on July 8 at Pinar del Río, Las Ovas and Puerta de Golpe; and on Júly 10 at Matanzas. In 1934 seen June 16 at Manacas.

20. Charadrius vociferus ternominatus Bangs and Kennard. Wes: Indian Killdeer. In 1933 two were observed June 30 at Santiago, ten July 7 at Pinar del Río, one July 8 at Víbora, and two were obtained July 6 at Guane. The species was observed June 18, 1934, at Cascajal and at Santo Domingo.

21. Larus atricilla Linnaeus. Laughing Gull. Gallego. Small numbers were seen around Cayo Francés and Caibarien from June 14 to 21, 1934, and on June 20 a fisherman at Caibarien brought me a living immature bird which he claimed he had just captured on one of the outlying keys. This specimen is now preserved in my collection. It was not large enough to have had any extended powers of flight, and is strong indication of the breeding of the Laughing Gull in this vicinity.

22. Sterna dougallii dongallii Montagu. Roseate Tern. Gaviota. One observed from a boat close to the shore of Cayo Santa María on June 14, 1934.

23. Sterna fuscata fuscata Linnaeus. Sooty Tern. Gaviota Monja. In 1934 three were observed off Cayo Santa María June 14; about one hundred off Cayo Francés on June 21, and twelve off Sagua the same day.

24. Sterna albifrons untillarum (Lesson). Least Tern. Two seen near Cayo Francés June 14, 1934, and two off Sagua June 21, 1934.

25. Thalasseus maximus maximus (Boddaert). Royal Tern. Gaviota. Two seen from a boat near the coast of Cayo Santa María June 14, 1934.

26. Columba leucocephala Linnaeus. White-crowned Pigeon. Paloma Cabeciblanca. Twenty were seen on Cayo Francés on June 14 and again on June 20, 1934.

6. 27. Zenaida aurita zenaida (Bonaparte). Zenaida Dove. Sanjuanera. In 1933 single birds or pairs were noted at Bayamo July 1; Sabanacú July 1; Herradura July 5, and Jatibonico July 10.

4. 28. Zenaida asiatica asiatica (Linnaeus.) White-winged Dove, Aliblanca. One seen at Santiago on June 30, and two at Bayamo, on July 11, 1933. 
29. Zenaidura macroura macroura (Linnaeus). Cuban Mourning Dove. Rabiche. Abundant and generally distributed on the main island, and five were seen on Cayo Francés on June 14, 1934.

30. Columbigallina passerina insularis Ridgway. Cuban Ground Dove. Tojosita. Common and generally distributed. A female was obtained at Sancti Spiritus July 2, 1933, and another at Guane July 5 , 1933. It was noted that the former had the bill dusky, and the legs and feet light pink with black claws.

31. Amazona leucocephala palmarum Todd. Western Cuba Parrot. Cotorra. While travelling in a bus on the Carretera Central near Jatibonico on July 1, 1933 a flock of twelve parrots was noter perched on the limbs of a leafless tree close to the roadside; they did not take flight when the bus passed. A fair number of parrots were observed around Sancti Spiritus on July 2 and 10, 1933, and on the latter date one was obtained as a specimen.

32. Aratinga euops (Wagler). Cuban Paroquet. Periquito. At Sancti Spiritus on July 3, 1933, a man came in from the country on horseback with a cage containing about 100 paroquets to sell as cage birds. When I returned to the town a week later all but two had been sold; those I purchased for the sum of ten cents apiece to preserve as specimens. From many reports the species is approaching the point of extermination in many parts of Cuba.

33. Coccyzus americanus americanus (Linnaeus). Yellow-billed Cuckoo. One observed at Santiago on June 30, 1933, and one on Cayo Francés on June 14, 1934.

34. Saurothera merlini d'Orbigny. Cuban Lizard Cuckoo. Arriero. A female specimen was obtained at Sancti Spiritus on July 2, and two at Guane July 5, 1933. The species was also observed at Viñales, Pinar del Río, Placetas, and Caibarien. The specimen obtained at Sancti Spiritus contained an egg nearly ready to be laid. The three stomachs were jammed with so much food that it seemed surprising a stomach could hold so much. It was composed entirely of arthropods, mostly insects and their larvae. The greater part consisted of Lepidopterous larvae. One stomach from Guane contained 22 of them, of a great variety of form and size, ranging from 3 large Sphingid caterpillars to 2 small Geometrids. This stomach had also 4 green stinkings (Nezara viridula), 2 large brown stinkbugs (Edessa sp.), 3 cicadas, a bush cricket, and a small beetle; also a parasitic nematode worm and 3 pieces of gravel. Another stomach (also from Guane) contained 16 large Iarvae of the Tobaceo Worm (Protoparce sexta jamaicensis); in ad- 
dition this stomach contained 11 eutworms, a scorpion 35 millimeters in length, a Tenebrionid beetle, and a June beetle (Phyllophaga sp.). No agriculturist who had seen the contents of this stomach would ever want an arriero killed on his property! The stomach from Sancti Spiritus contained 5 cutworms, 1 Nezara viridula, and some unidentifiable insect fragments.

35. Crotophaga ani Linnaeus. Ani. Judío. Common. Observed at many loealities. Specimens were brought in at Guane.

36. Chordeiles minor gundlachii Lawrence. Cuban Nighthawk. Querequeté. Three specimens were obtained at Guane on July 5 and 6,1933 . In addition the species was recorded at Jatibonico on July 1, Mendoza July 5, and Ciego de Avila July 10, 1933, and at Manacas June 18, 1934. The three stomachs contained exclusively insects, of which Cicadas formed 20 per cent, and the balance consisted of Coleoptera except for one Pentatomid bug (Thyanta sp.) amounting to 1.3 per cent. Small June Beetles (Phytalus apicalis) formed 37 per cent. Other beetles recognized were larger June Beetles (Phyllophaga sp.) ; manure beetles (Ataenius sp.); Bostrichidae (Apate francisca); Click Beetles (Pyrophorus sp.); green weevils (Exopthalmoides sp.), and Tenebrionidae.

37. Tachornis phoenicobia yradii (Lembeye). Cuban Palm Swift. Observed in small numbers in July 1933 at Jiguaní, Bayamo, Camagüey, Ciego de Avila, Jatibonico, Taco Taco, and Cascajal; and on June 16, 1934, at Manacas.

38. Ricordia ricordii ricordii (Gervais). Cuban Hummingbird. Observed at Bayamo July 1, 1933, Viñales July 7, 1933, and on Cayo Francés June 14, 1934, and two specimens were obtained at Guane July 6, 1933.

39. Priotelus temnurus temmurus (Temminek). Cuban Trogon. Tocoloro. One observed on a limestone hill near Viñales July 7, 1933 ; it was then captured for us by a birdeatcher with a long pole tipped with bird lime.

40. Todus multicolor multicolor Gould. Western Cuba Tody. Pedrera. Observed at Sancti Spiritus on July 2 and Viñales July 7, 1933. At Guane on July 5 and 6 large numbers were brought in, three of which were preserved as specimens. Their stomachs contained nothing but insect material. Small Lepidopterous larvae formed 46 per cent, Coleoptera 32 per cent, and small Diptera 22 per cent of the contents.

41. Todus multicolor exilis Barbour and Brooks. Eastern Cuba Tody. Three were noted near Santiago June 30, 1933. Their note 
was a clacking clippy-clippy-clip, surprisingly different from that of the Puerto Rican bird I had just been hearing.

42. Xiphidiopicus percussus percussus (Temminck). $\mathrm{Cuban}$ Green Woodpecker. Carpintero Verde. At Sancti Spiritus on July 2 , 1933, a pair was observed feeding young in a nesthole in a leguminous tree. The entrance was surprisingly small for the size of the bird. The male of this pair was collected with a slingshot. At Guane on July 5 and 6 many specimens were brought in. The species was observed at Cabaiguán on July 3, and Pinar del Río on July 7, 1933. On Cayo Francés June 14, 1934, one was collected at a nest hole in a dead tree in a mangrove swamp. The contents of 4 stomachs were examined. The three from the main island contained exclusively vegetable material, consisting mostly of small unidentified drupes, and also some splinters of wood, perhaps swallowed while excavating a nesting cavity. The stomach of the bird from Cayo Francés was greatly distended with a large ground lizard and one small seed.

43. Centurus superciliaris supercitiaris Temminck. Cuban Ladder-backed Woodpecker. Carpintero Jabado. Observed at Matanzas on July 3 and at Pinar del Río July 7, 1933. At Guane on July 5 twenty were brought in by boys who had obtained them with slingshots. It was possible to save only two of these as specimens, but the stomach contents of six were examined, and found to consist of 57.2 per cent of animal matter and 42.8 of vegetable. Cutworms formed 8.8 per cent of the food; June Beetles ( 8 in one stomach and 9 in another) constituted 22.5 per cent; other Coleoptera and their larvae (including a Cerambycid beetle) formed 21 per cent. The vegetable matter consisted of the remains of fruits which it proved impossible to identify. The above evidence goes to prove that this bird does much good to offset its well known injurious habits of destroying cultivated fruits and growing corn.

44. Colaptes chrysocaulosus chrysocaulosus Gundlach. Cuban Flicker. Two of these rare birds seen near Bayamo on July 1, 1933.

45. Nesoceleus fernandinae (Vigors). Fernandina's Flicker. Carpintero Churroso. One seen along the Bayamo-Holguin Road on July 1, 1933.

46. Tyrannus dominicensis dominicensis (Gmelin). Gray King. bird. Pitirre. Common and generally distributed on the main island; noted on Cayo Francés June 14, 1934. Several specimens were brought in at Guane July 6, 1933, but only one was saved as a specimen. Its stomach contained fragments of Coleoptera and gravel. 
47. Tolmarchus caudifasciatus (d'Orbigny). Cuban Petchary. Observed at Pinar del Río and Viñales July 7, and at Camagüey July 11, 1933. At Guane on July 5 twenty-five were brought in. It was possible to save only two as specimens, but the stomach contents of seven were examined. One was empty; the others contained 75.3 per cent of animal matter and 24.7 per cent of vegetable. The animal matter consisted entirely of insects and their larvae, among which the following were recognized: Cutworms 14.1 per cent; crane flies 6.7 per cent; Cryptocephalus fleabeetles (C. nigrocinctus and other species) 10.8 per cent; Meloidae 6.6 per cent; miscellaneous Coleoptera 2.2 per cent, and a large cicada 13.6 per cent. The vegetable matter consisted mainly of drupes and other small fruits, among which were some of Chalcus exotica.

48. Blacicus caribaeus (d'Orbigny). Cuban Pewee. San Juanito. Abundant at Sancti Spiritus on July 2, 1933. Three families of young just out of the nest being fed by their parents were noted. A boy killed seven with a slingshot, all of which were preserved as specimens. The note was recorded in the field as "a whistled wheetwheet". It was called San Juanito locally to distinguish it from the Myiarchus, which is known as Bobito. The seven stomachs contained exclusively insects. Hymenoptera dominated, forming 41.2 per cent, consisting of Eumenid bees (Monobiella atrata) in four stomachs, 36 per cent; and Halictid bees (Agapostemon) in two stomachs, 5.2 per cent. Lepidoptera came second with 20 per cent; consisting of 6 medium-sized moths in one stomach and 1 in another. Diptera formed 12.9 per cent, including Syrphid and other flies. Coleoptera and Isoptera each formed 7.1 per cent, the latter consisting of some large black-winged Termites. Hemiptera constituted 6.0 per cent (a large green stinkbug). Odonata amounted to 5.7 per cent (small damselflies). Judging by this sample the species is of more or less neutral importance, consuming beneficial as well as in. jurious insects.

49. Progne cryptoleuca Baird. Cuban Martin. Golondrina Noted at Santiago, Sancti Spiritus, Manacas, Havana, Pinar del Río, Matanzas, Ciego de Avila, Caibarien, and on Cayo Francés. In the latter locality on June 14, 1934, ten were observed nesting in boles in dead trees in mangrove swamps. As the boat lay at anchor half a mile off Cayo Francés on June 21, 1934, one kept alighting on its flagpole until it was collected. Its stomach contained 2 dam. selflies, a small Coreid bug, fragments of Coleoptera, and other unidentifiable inseets. 
50. Petrochelidon fulva cavicola Barbour and Brooks. Cuban Cliff Swallow. Golondrina. Many were observed apparently nesting on high limestone eliffs near Viñales July 7, 1933. That same year the species was recorded at Santiago on June 30 and July 12; at Sancti Spiritus July 1-3; at Bacunagua and Palacios on July 5, and a male was obtained at Guane on July 6. At Caibarien June 15-20, 1934, these swallows were abundant, nesting under the eaves of houses in the town. An adult and a juvenile specimen were obtained there on June 20. Two stomachs contained nothing but finely comminuted Diptera and Coleoptera.

51. Corvus nasicus Temminck. Cuban Crow. Cao Montero. A pair was seen near Esperanza on July 3, 1933.

52. Mimus polyglottos orpheus (Linnaeus). Cuban Mockingbird. Sinsonte. Abundant and widely distributed. A single mockingbird heard singing on Cayo Francés June 14, 1934, may have been this species. At Guane on July 6, 1933, many adults and nestlings were brought in, but it was possible to preserve only one adult as a specimen. Its stomach contained 11 eutworms ( 85 per cent) and 1 drupe.

53. Mimocichla rubripes rubripes (Temminck). Western Cuba Thrush. Zorzal Real. Ten were seen at Sancti Spiritus on July 2, 1933. Several were brought in at Guane on July 5, 1933, one of which was preserved as a specimen. A flock of six was seen at Remedios on June 16, 1934. Two stomachs from Guane contained 90 per cent of insects and 10 per cent of fruit. Cutworms amounted to 40 per cent. One stomach eontained 3 large Staphylinid beetles.

54. Polioptila lembeyei (Gundlach). Cuban Gnatcatcher. Sinsontillo. On July 2, 1933, my friend Mr. G. C. Bucher of Santiago took us to a place near the shore of Níspero Bay, east of Santiago, where we observed two of these little birds singing their sprightly song in the dry brushy coastal growth. The birds flitted about actively, and when singing perched on rather conspicuous perches in the bushes, but soon moved on to another spot to continue their song. Mr. Bucher tells me that the species is locally very common in this region.

55. Vireo calidris barbatula (Cabanis). Black-whiskered Vireo. Bien-te-veo. In 1933 observed at Santiago, Cobre, Sancti Spiritus, Guane, and Viñales; and in 1934 at Caibarien. Several were brought in at Guane, and one was saved as a specimen. It had eaten some small red berries.

56. Vireo gundlachii Lembeye. Gundlach's Vireo. Juan-chiví. In 1933 noted at Sancti Spiritus July 2, Guane July 6, and Viñales 
July 7. A specimen was obtained at Guane. Its stomach contained two rather small eicadas, a berry, and a drupe. On Cayo Francés June 14, 1934, two were observed, one of which was secured, but it was too much damaged by the shot to save as a specimen.

57. Passer domesticus domesticus (Linnaeus). English Sparrow. Common in cities and towns at least as far east as Ciego de Avila. Other towns in which it was noted as being common are Guane, Pinar del Río, Havana, Saneti Spiritus and Caibarien.

58. Agelaius humeralis (Vigors). Cuban Red-winged Blackbird. Mayito. In 1933 observed at Sancti Spiritus July 2; Sábalo July 5; Guane July 6; and Bacunagua July 8 (flock of 200), and in 1934 at Remedios and Cascajal on June 16. Four were brought in at Guane. Two stomachs contained cutworms 55 per cent and grasshoppers 45 per cent.

59. Icterus hypomelas (Bonaparte). Cuban Oriole. Solibio. Common. At Sancti Spiritus on July 2, 1933, a pair was observed feeding a family of three young scarcely able to fly. One of the young was collected with a slingshot. At Guane on July 5,'1933, twenty were brought in, in all plumages, including many nestlings. Three of the Guane birds were preserved as specimens. In addition to the localities mentioned, Orioles were observed at Holguin July 1, Viñales and Pinar del Río July 7; Bacunagua July 8, 1933; Taguayabón June 16, and Santa Clara June 18, 1934. Four stomachs contained 76.2 per cent of Lepidopterous larvae (24 per cent being cutworms, 17.5 per cent Pyralids, and the rest miscellaneous); 12.5 per cent of other insect remains; 7.5 per cent of white eggshell; and 3.8 per cent of minute seeds.

60. Holoquiscalus jamaicensis caribaeus Todd. Western Cuba Wedge-tailed Grackle. Chinchiguaco. Observed in 1933 at Colón on July 3, Rincón July 5, San Franciseo on July 10.

61. Holoquiscalus jamaicensis gundlachii (Cassin). Eastern Cuba Wedge-tailed Grackle. Observed at Baire, Bayamo, Holguin and Ciego de Avila on July 1, 1933. On June 14, 1934, a female was collected from a flock of ten on Cayo Francés. It had eaten some refuse from fish being cleaned by some of the inhabitants near the shore.

62. Ptiloxena atroviolacea (d'Orbigny). Cuban Grackle. Totí. Common. Observed in 1933 at Palma Soriano, Sancti Spiritus, Esperanza, Guane, Viñales, Pinar del Río, Candelaria and San Francisco; and in 1934 at Remedios, Cama Juaní and Santa Clara. Two specimens were preserved at Guane on July 5, 1933. Three 
stomachs from that locality contained 72 per cent of animal matter and 18 per cent of vegetable matter. All three stomachs contained cattle ticks which were identified by the U. S. Bureau of Entomology as Boophilus anmulatus australis. One was found in one stomach, six in another, and fifty-eight in the third; together they constituted 16.6 per cent of the food. All three stomachs also contained cutworms (seven, twelve, and sixteen), forming 45 per cent of the food. A Diaprepes weevil and some Coleopterous larvae formed the balance of the animal material. The vegetable matter consisted of some unidentifiable fruits. Judging by the large numbers of cattle ticks and cutworms eaten, this species appears to be highly beneficial.

63. Sturnella magna hippocrepis (Wagler). Cuban Meadowlark. Sabanero. Abundant throughout the pasture and savanna lands. The song is very loud, resembling that of $S$. neglecta somewhat in that respect, but otherwise more like that of S. magna magna. Six were brought in at Guane on July 6, of which two were preserved as specimens. Eleven cutworms in one stomach and twenty-four in the other formed 90.5 per cent of the food. The balance was composed of a cockroach, a weevil, and two hard black seeds.

64. Spindalis pretrei (Lesson). Cuban Spindalis. Cabrero. At Viñales on July 7, 1933, a male was observed singing in rank vegetation by a stream. The song was recorded in the field as a wiry swee-swee-sweet-sweester, a little louder and not quite so high pitched as the song of $S$. portoricensis.

65. Tiaris olivacea olivacea (Linnaeus). Yellow-faeed Grassquit. Cencerinico in Oriente; Barbito in Santa Clara. Common and generally distributed. Specimens were obtained at Sancti Spiritus July 2, 1933, and at Guane July 6, 1933. Stomachs contained small seeds, mainly leguminous.

66. Tiaris canora (Gmelin). Melodious Grassquit. Tomeguin. In 1933 one was noted at Holguin on July 1, and on July 5 at Guane six were brought in, three of which were preserved as specimens.

67. Melopyrrha nigra (Linnaeus). Cuban Black Finch. Negrito. Eight were brought in and two preserved as specimens at Guane on July 5, 1933. The stomachs contained small seeds and sand for grinding purposes.

Remarks on the Introduction of Cuban Birds Into Puerto Rico

In general the writer does not approve of introducing birds or other animals from one place to another. In many cases such introductions have been followed by sad consequences, witness the 
introduction of the mongoose into the West Indies, of the English Sparrow and Starling into the United States, of the Mynah into Hawaii, and of Rabbits into Australia. Animals which may be harmless or actually beneficial in their natural homes, when transplanted to a new region where different biological factors are involved, and where they do not have their natural enemies to keep their numbers within bounds, may become excessively abundant and devlop new and extremely injurious habits. However, there are a few species which it is scarcely believable could become injurious, and which might be very desirable for introduction purposes, a real need being felt for birds which occupy certain particular niches in the economic scheme.

One important fact must be borne in mind in connection with any attempted bird introductions into Puerto Rico. Due to the prevalence of the mongoose here the introduction of any ground. nesting birds would be extremely inadvisable, as the mongoose would exterminate them before they ever had a chance to become established. That has already happened in the case of the Quail, which were introduced a short time before the mongoose was brought in. This state of affairs is much to be regretted, as there are many useful and attractive birds which would be most desirable for introduction except for this condition.

In the lines which follow discussion will be found of a number of species of Cuban birds which have been mentioned in connection with various projects for the introduction of birds into Puerto Rico, or which occur to the writer as being possibly desirable for introduction. In connection with each, reasons are given to show why the bird in question might be desirable or undesirable, and a suggestion of some of the obstacles which might have to be overcome in connection with the introduction of some of them.

Phoenicopterus ruber Linnaeus. Flamingo. Flamenco. Many suggestions have been made for the introduction of the Flamingo, but that would be highly impracticable. Flamingoes once occurred here, but became locally extinct many years ago due to persecution, as they cannot endure densely inhabited regions. They cannot live long at fresh water lakes due to lack of the small molluses which constitute their entire natural food, and which occur only in saline mudflats. Suitable areas for the Flamingo in Puerto Rico are very limited, and too much frequented by man.

Aix sponsa (Linnaeus). Wood Duck. Huyuyu. A most beautiful and gorgeously colored small duck which is highly ornamental as 
well as of value for its flesh. It is not injurious in its food habits, feeding mostly on insects, with the addition of a few small fish. frogs and snails, and a great variety of vegetable food, including aquatic plants, and various fruits and seeds found near the water. It inhabits particularly streams the banks of which are wooded, and prefers sluggish streams to those which are swiftly running. It would probably suffer but little from the mongoose, as it nests in hollow trees far above the ground. It occurs in the southern United States as well as in Cuba, and is much more common on the continent.

Cathartes aura aura (Linnaeus). Turkey Vulture. Aura. This species has already been introduced from Cuba into Puerto Rico. The introduction took place many years ago, but as yet the Puerto Rican range of this useful carrion-eating bird is restricted to the southwestern part of the island.

Jacana spinosa violacea (Cory). West Indian Jácana. Gallito. This brilliantly colored little bird has toes so long and slender that it can walk over the surface of water which has even a slight amount of aquatic vegetation, and thus gives the impression of actually walking on the water. In Cuba it occurs commonly on almost every lake and pond, even on small roadside pools, so that it forms a conspicuous feature of the avifauna. There are an abundance of places in Puerto Rico where this bird should thrive, and it lays its eggs on the leaves of water plants in places difficult for the mongoose to reach. Birds collected in Jamaica and the Dominican Republic by the writer had consumed nothing but insects, evidence that the species is beneficial in its habits. It appears to be a desirable species for introduction.

Zenaidura macroura macroura (Linnaeus). Cuban Mourning Dove. Rabiche. This dove is extremely abundant in Cuba, despite constant persecution. It is able to maintain its abundance despite intensive cultivation and constant hunting better than any of the other native pigeons. For this reason it would seem to be a desirable bird for introduction to Puerto Rico, where game birds are scarce. It nests in trees well out of reach of the mongoose.

Tyto perlata furcata (Temminck). Cuban Barn Owl. Lechuza. This large owl is found everywhere in Cuba, around farmyards, church towers, limestone cliffs and caves, and in many other situations. Its principal food consists of rats, but it must be admitted that it does consume some poultry and small birds. On the whole it is much more beneficial than injurious, and its introduction into Puerto Rico would probably prove to be of value. 
Priotelus temnurus temnurus (Temminck). Cuban Trogon. Tocoloro. "The most beautiful bird in the world", as the Cubans call this bird, occurs commonly in Cuban thickets and woodlands, where it attracts much attention from its gorgeous plumage and its tameness. The eggs are laid in abandoned woodpecker holes, securely out of reach of the marauding mongoose. Its food apparently consists mainly of insects mixed with some wild fruits. This, or other trogons, would be a great attraction to visitors, and probably in the main beneficial to agriculture.

Tachornis phoenicobia yradii (Lembeye). Cuban Palm Swift. Golondrina or Vencejo. These little swifts live in colonies in clumps of palm trees which dot the savanna lands in Cuba. They are exclusively insectivorous, and highly beneficial. Their introduction into Puerto Rico should prove highly beneficial. The chief obstacle to their introduction would be the problem of catching a sufficient number at one time, and then getting them to Puerto Rico very expeditiously. As their food consists entirely of insects captured on the wing it is impossible to keep them long in captivity. They could perhaps be captured by dropping a large net over a nesting colony at night, and then the birds could be transported by airplane to Puerto Rico.

Myiadestes elizabeth elizabeth (Lembeye). Cuban Solitaire. Ruiseñor. This bird is one of the finest songsters in the western hemisphere, and well deserves the name of "nightingale" from its flutelike notes. It seems strange that Puerto Rico should have no Solitaire, as each of the Greater Antilles except Puerto Rico, and even each of the Lesser Antilles boasting of any high mountains, has a form of Solitaire. They are birds of high mountain forests, and those of El Yunque and other high mountains in the central part of the island seem admirably adapted for their needs. They would prove a great attraction to visitors at the park at El Yunque and at other places. Their introduction could not help but be beneficial, and the birds may be easily obtained from bird catchers in Cuba.

Ptiloxena atroviolacea (d'Orbigny). Cuban Grackle. Toti. Choncholí. The beneficial habits of this bird in consuming cutworms, ticks and other injurious arthropods have been elaborated upon earlier in this paper. Catching and transporting these birds should constitute no great problem, and they should not fall an easy prey to the mongoose. The only doubt that might be entertained about 
their introduction is that there might be some danger of our native Grackle (Holoquiscalus niger brachypterus) being adversely affected by competition with the imported bird, but this seems hardly likely, as Ptiloxena and Holoquiscalus get along very well together in Cuba, and indeed are frequently seen flocking together. 